\title{
Design and Performance Evaluation of Decentralized Wastewater Treatment and Reuse System for Urban and Rural Places
}

\author{
C. Ramprasad*1; Bharathwaj, R. R²; Debesh Poddar ${ }^{2}$ \\ ${ }^{1}$ Assistant Professor, School of Civil Engineering, SASTRA Deemed to be University, Thanjavur, India. \\ ${ }^{2}$ Graduate Student, School of Civil Engineering, SASTRA Deemed to be University, Thanjavur, India.
}

\begin{abstract}
:
The increasing need of water and depleting availability of water resources pressed the research world look for an alternative solution by treating the wastewater discharged from domestic dwellings for secondary reuse. It has proved to be an effective way to overcome this problem. The improper functioning of centralized treatment systems and huge cost involved for the operation and maintenance paved a way for the Decentralized Wastewater Treatment Systems (DEWATS). In the present study, two treatment approaches were evaluated in detail. Constructed wetlands and MBBR, for a residential complex in Rural and Urban sectors respectively. The systems are designed with the help of quantifiable data including the population, area available and various chemical properties of the wastewater discharged. The performance of the systems were monitored for a period of time and showed a good quality water that can be used for secondary applications like toilet flushing or gardening.
\end{abstract}

Keywords: Wastewater Treatment; Decentralized; Geographic factors; Constructed wetlands; MBBR

\section{INTRODUCTION}

The construction and operation of the large scale centralized wastewater treatment systems with sewer networks are challenging task for the facility providers. Generally, the centralized sewer networks are laid inline with the water supply networks, and sometimes the failure in sewer pipes leading to potable water contamination. The Indian government and urban local bodies (ULBs) are also facing the similar problem of providing safe and secure drinking water and treating the generated wastewater in an environmental friendly and economical means for the rapidly growing population. India is experiencing an exponential growth in last few decades, in the population as well as in economic / industrial growth. Due to the above scenarios the available centralized treatment facilities are showing an abysmal performance and hence the ground water and surface water sources are highly contaminated (Cossio et al., 2018).

Due to increasing population and industrialization in the country, the per capita average annual freshwater availability started to reduce from $1869 \mathrm{cu}$. $\mathrm{m}$ in 2001 to $1588 \mathrm{cu}$. $\mathrm{m}$ in 2010, and it's expected to reduce to $1341 \mathrm{cu}$. m by 2025 and further down to $1140 \mathrm{cu} . \mathrm{m}$ in 2050 . Hence, there is an urgent need for efficient water resource management through enhanced water use efficiency and wastewater recycling (Kaur et al., 2012; CPCB, 2017). The planning commission of India (Now NITI Aayog) reported on the urban developments in their $12^{\text {th }}$ five year plan (2012-2017) that 4861 cities and town in India lack a basic sanitation facilities and metropolitan cities such Chennai and Bengaluru have only 50\% of sewerage network. The amount of wastewater generated in the country and actually available treatment facilities are having huge disparities. The amount of sewage generated in Indian class I cities 61754 million liters per day (MLD) and treatment capacities available are 22963 MLD (32\%). The total treatment capacity gap between the waste water generation and its treatment in Class I (498) and Class II (410) cities of India combined is also as high as $70 \%$. The below Figure 1(a) and (b) gives the detail of the same (Kaur et al., 2012). The overall sewage treated in India was found to be nearly $30 \%$ and $70 \%$ is untreated.

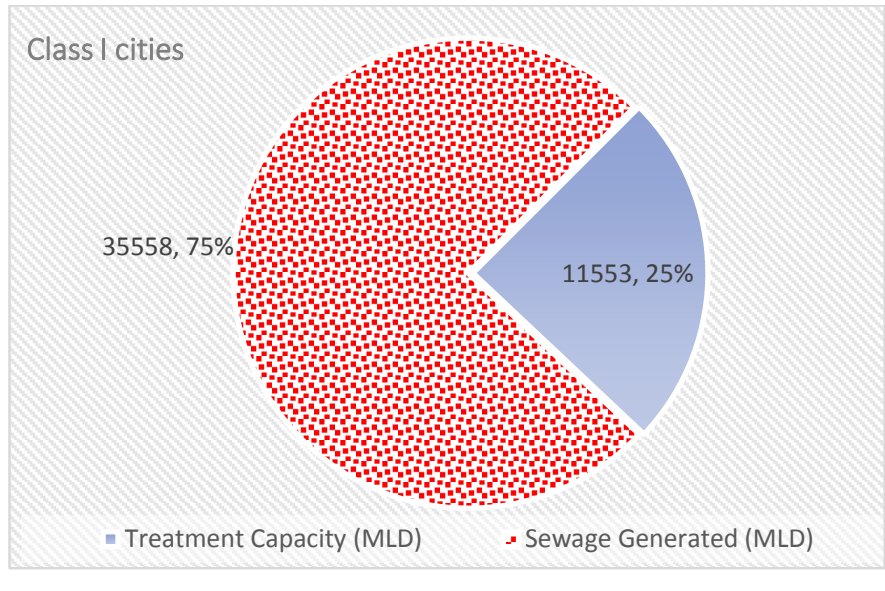

Fig 1(a) Wastewater generated and treated in Class I cities (498)

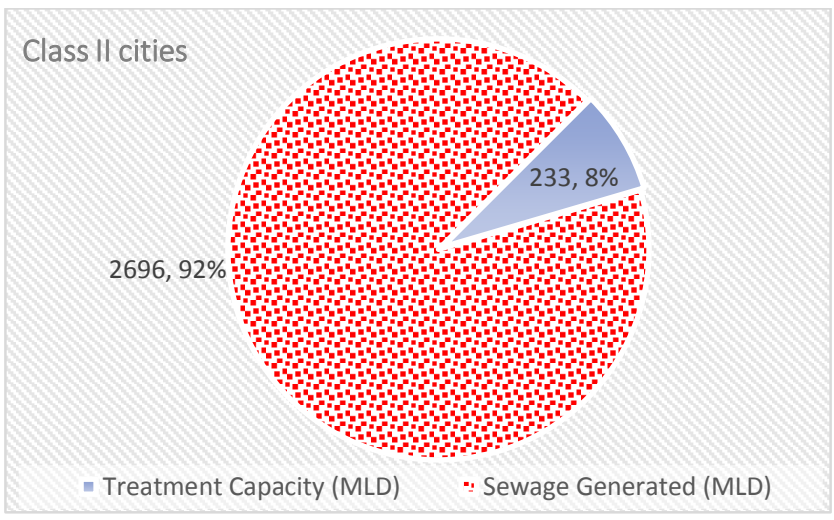

Fig 1(b) Wastewater generated and treated in Class II cities (410) 
The centralized treatment system involves huge capital cost for laying the sewer networks and the laid sewer networks have inequality in providing services and coverage to the low income areas. At the current scenario in the progress of waste management, India will take several decades to have a safe disposal mechanism. The suitable ways to tackle the problem of waste management in India is adopting a hybrid scenario. The hybrid approach is having both centralized and decentralized treatment ways and abates the water scarcity issues and eradicate rising levels of water pollution. The abysmal performance of centralized approach suggests that India needs to adopt decentralized model of wastewater treatment and reuse. Additionally, the Indian policies are not very stringent to treat the domestic wastewater before discharging from any housing unit except Bengaluru. Therefore, there is huge scope for the design and implementation of sustainable decentralized wastewater treatment (DWWT) systems. The decentralized wastewater treatment systems are found to be very effective in treating the domestic wastewater from an apartment or a community (Parkinson and Tayler, 2003; Bdour et al., 2009; Wu et al., 2015; Ramprasad and Kutty, 2016; Ramprasad et al., 2017). The objective of the report; (i) to study the various decentralized treatment options and prepare a decision matrix for secondary treatment applications, (ii) to choose a suitable treatment option for an urban and rural community and (iii) to evaluate the performance of a decentralized systems (The MBBR unit and The constructed wetland) in treating the wastewaters generated in urban and rural sectors respectively.

\subsection{Decentralized wastewater treatment system}

Decentralized wastewater treatment (DWWT) system is defined as "the collection, treatment, and disposal/reuse of wastewater from individual homes, clusters of homes, isolated communities, industries, or institutional facilities, as well as from portions of existing communities at or near the point of waste generation" (Tchobanoglous et al., 2003).

These systems have different treatment options and an ideal treatment option area chosen based on different factors and treatment options include

1. Activated sludge process (ASP)

2. Anaerobic baffled wall reactor

3. Bio-towers (BT)

4. Constructed wetlands $(\mathrm{CW})$

5. Extended aeration process (EA)

6. Membrane bioreactors (MBR)

7. Moving bed bio-film reactor (MBBR)

8. Packaged treatment plants

9. Sequential batch reactors (SBR)

10. UASB (anaerobic digesters) followed by constructed wet lands

11. Waste stabilization ponds (WSP) or

12. Any other technology able to meet the required treatment efficiency

Selection of an ideal treatment system is determined with help of selection matrix provided in Table 1. The following table corresponds to the various factors and the respective results for different treatment types. In addition to this, the locality for the treatment system must also be analysed with various factors, as the situation varies with condition likes public acceptance, climatic factors etc..,

Table 1 Decision Matrix for Secondary Treatment Processes

\begin{tabular}{|c|c|c|c|c|c|c|c|c|c|c|}
\hline Process & $\begin{array}{l}\text { Effluent } \\
\text { Quality }\end{array}$ & $\begin{array}{l}\text { Coliform } \\
\text { removal }\end{array}$ & $\begin{array}{l}\text { Nitrification- } \\
\text { Denitrification }\end{array}$ & $\begin{array}{l}\text { Phosphorous } \\
\text { removal }\end{array}$ & $\begin{array}{l}\text { Process } \\
\text { Reliability }\end{array}$ & $\begin{array}{l}\text { Land } \\
\text { Use }\end{array}$ & $\begin{array}{c}\text { Ease of } \mathrm{O} \\
\& \mathrm{M}\end{array}$ & $\begin{array}{c}\text { Energy } \\
\text { Recovery }\end{array}$ & $\begin{array}{c}\text { Electrical } \\
\text { Demand }\end{array}$ & $\begin{array}{c}\text { Capital } \\
\text { Cost }\end{array}$ \\
\hline ASP & ++ & ++ & -- & -- & +++ & ++ & ++ & +++ & + & + \\
\hline EA & +++ & ++ & -- & -- & +++ & + & +++ & -- & -- & ++ \\
\hline MBR & +++ & +++ & -- & -- & ++ & +++ & -- & -- & -- & -- \\
\hline MBBR & +++ & +++ & + & -- & ++ & +++ & -- & -- & + & ++ \\
\hline SBR & +++ & +++ & ++ & +++ & ++ & +++ & ++ & -- & + & -- \\
\hline $\begin{array}{l}\text { UASB + } \\
\text { ASP }\end{array}$ & ++ & ++ & -- & -- & ++ & ++ & + & ++ & + & + \\
\hline WSP & + & -- & -- & -- & -- & -- & + & -- & +++ & ++ \\
\hline $\begin{array}{l}\text { Hybrid. } \\
\text { CW }\end{array}$ & +++ & + & + & + & ++ & -- & + & ++ & +++ & ++ \\
\hline
\end{tabular}

Poor (--); Average (+); Good (++); Very Good (+++) (Adapted from MoUD manual, 2012) 


\subsubsection{Advantages of Decentralized Wastewater Management Systems (DWWMs)}

1. Flows at any point in the system would remain small, implying less environmental damage from any mishap.

2. System construction results in less environmental disturbances as smaller pipes would be installed at shallow depths and could be more flexibly routed.

3. The system expansion is easier, new treatment centres can be added without routing ever more flows to existing centres.

4. Entry of industrial waste could be more easily monitored.

5. Sector wise treatment is permits sewage transmission over shorter distances.

6. Treatment units are close knit and are free from odours and insects.

7. Lesser investment is required for the sewer pipelines.

8. Community participation is essential; hence people can participate in the monitoring of the system performance. This instils confidence among the people.

9. Quality of treatment is more efficient than traditional system due to accurate estimation of wastewater generation and lower quantity of wastewater.

10. Treated sewage can be effectively used within the sector for applications like toilet flushing, landscape irrigation and cooling tower make ups.

11. Maintenance of the sewerage system is easier.

\subsubsection{Disadvantages of DWWMs}

1. Policies regarding installation, operation and maintenance are not yet well established in many of the developing countries.

2. Standardization of the systems is difficult as significant variation exists with regard to technical design to suit the local geography and climatic conditions.

3. Local people will have to bear all by themselves the O\&M of the treatment plant.

4. Getting a site for the STP may be difficult amidst built up sections and eventually, only the graveyards or cemeteries have to be the site.

\section{MATERIALS AND METHODS}

\subsection{Site Selection}

The site was selected based on the geographical and economical division classified by the Indian government as rural area and urban areas (Census, 2011). The urban areas are the one densely populated with at least 400 persons per sq. $\mathrm{m}$, while the rural areas are the one that are less densely populated. A representation from each category was chosen for the study with urban area focusing on Bengaluru (GPS coordinates: $\left.12.96991^{\circ} \mathrm{N}, 77.59796^{\circ} \mathrm{E}\right)$ and rural area focusing on Vandaloor (GPS coordinates: $10.7285^{\circ} \mathrm{N}$, $79.0184^{\circ} \mathrm{E}$ ). The GPS map showing the two locations of the proposed DWWT are in Figure 2.

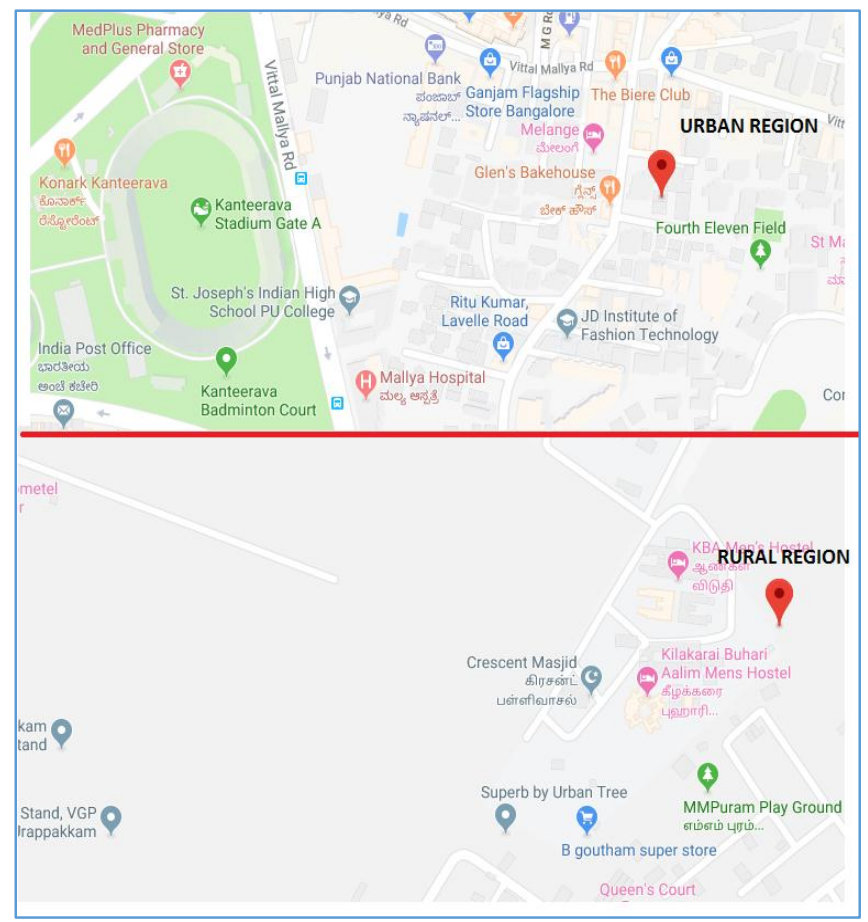

Fig 2. GPS map showing the two locations for the proposed DWWT

\subsection{Analytical methods}

3. Various physico-chemical parameters $\mathrm{pH}$, Temperature, Electrical conductivity (EC), Turbidity,

4. Oxidation reduction potential potential(ORP), Dissolved oxygen (DO), Solids ( TS, TSS, TDS),

5. Total alkalinity, Total hardness, Nitrate, Ammonia, Phosphate, Chlorides, Sulphate, Fluoride,

6. Sodium, Iron, BOD, COD and biological parameters like total Coliform(TC) and pollutants of

7. interest includes Humic acid and anionic detergents like Sodium Doecyl Sulphate (SDS) were

8. determined by standard methods and also parameters like $\mathrm{pH}$, alkalinity, Hardness, chlorides,

9. Nitrate, iron, Fluorides are tested using water quality test kit

Various physico-chemical parameters $\mathrm{pH}$, Temperature, Electrical conductivity (EC), Turbidity, , Dissolved oxygen (DO), Total suspended solids (TSS), Total dissolved solids (TDS), Total solids (TS), Nitrate, Ammonia, Phosphate, biochemical oxygen demand (BOD), Chemical oxygen demand (COD) and Fecal Coliform (FC) were determined by procedures as prescribed in the standard operating manual for water and wastewater (APHA, 2012). 


\subsection{Experimental setup}

The experimental setup for the urban and rural areas was designed based on the wastewater generated and the BOD concentration. It was found that for a rural sector to treat a single household wastewater of $40 \mathrm{~L}$, the area required to have a constructed wetland as treatment technology was $0.5 \mathrm{~m} \mathrm{x}$ $0.5 \mathrm{~m} \times 0.5 \mathrm{~m}$. The wetland was made up of plastic crates as shown in Figure 3 with a bed slope of 1 in 40 and filled with local available materials like sand and gravel. The plant species used in the treatment process was also a native variety commonly known as 'common reed' or Phragmites australis.

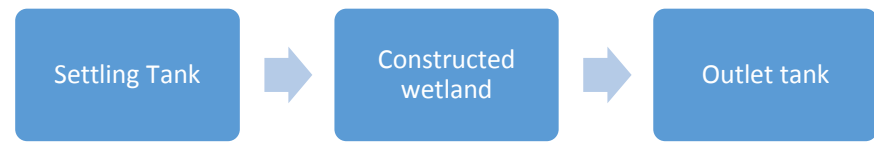

Fig 3 Schematic representation of experimental setup for rural area - Constructed Wetland (CW)

The treatment method adopted in the urban sector for the generated wastewater is moving bed biofilm reactor (MBBR) with a pre-treatment stage and a post treatment stage. The schematic representation of the MBBR system is shown in Figure 4. The MBBR unit area required to treat a $56 \mathrm{cu}$. $\mathrm{m}$ of wastewater generated in an apartment per day was found to be $1 \mathrm{~m}$ in dia and $4 \mathrm{~m}$ in height. The pretreatment (screening) and a post treatment (carbon filter and sand filter plus chlorination) are provided to treat the generated wastewater. The performance of both the treatment systems, MBBR and $\mathrm{CW}$ were evaluated by checking the raw and treated water quality.

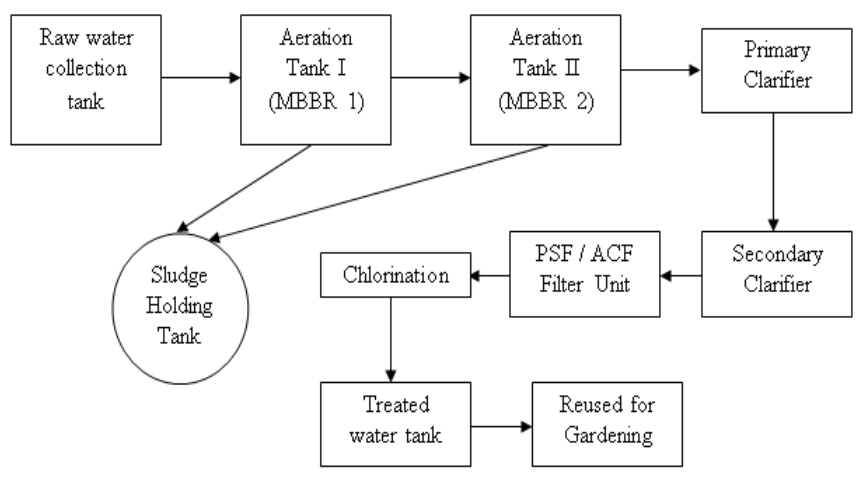

Fig 4 Schematic representation of MBBR unit adopted in urban area

\section{RESULTS AND DISCUSSION}

\subsection{Performance evaluation of Rural DWWT}

At first the rural wastewater was characterized for various wastewater parameters and the value was tabulated in Table 2. The wastewater characteristics highly depends on the water consumption, source of waste generation and life style of people (Leitao et al., 2006). It was found that biochemical oxygen demand (BOD) of the raw wastewater was in the range of $80-550 \mathrm{mg} / \mathrm{L}$ and chemical oxygen demand (COD) in the range of $250-1000 \mathrm{mg} / \mathrm{L}$. The $\mathrm{pH}$ and turbidity of the wastewater from the rural sector was observed to be 6.2-8.4 and 24-550 NTU respectively. The turbidity level was varying significantly due to the water consumption and source of waste generated. The temperature was found to be much higher $(38.9 \mathrm{C})$, it may be due to use of warm water for personal hygiene. Similar results were reported by Eriksson et al., 2002 and Bukhari, 2008. The electrical conductivity of the wastewater was found to be in the range of $2.12-2.44 \mathrm{mS} /$ $\mathrm{cm}$. The suspended solids concentration was also found be $200-1300 \mathrm{mg} / \mathrm{L}$ and dissolved solids was found to be 250 $5000 \mathrm{mg} / \mathrm{L}$. The nutrients concentration in the rural wastewater for Nitrate - Nitrogen was 44.1 to $121 \mathrm{mg} / \mathrm{L}$, Ammonia - Nitrogen was 36.2-89.1 mg/L and phosphate was 20.8-26.4 $\mathrm{mg} / \mathrm{L}$. The fecal coliform level in the rural wastewater was found to be in the range of $33 \mathrm{e} 4-54 \mathrm{e} 6$ and the level of oil and grease in the rural wastewater was in the range of $12-30 \mathrm{mg} / \mathrm{L}$. The characteristics of the rural wastewater was in good agreement with the previous researchers (Halalsheh et al., 2008; Chen et al., 2016; Ramprasad et al., 2017).

Table 2. Rural wastewater characteristics

\begin{tabular}{|c|c|c|c|}
\hline Parameters & Unit & $\begin{array}{c}\text { Rural } \\
\text { Wastewater } \\
\text { concentration }\end{array}$ & $\begin{array}{c}\text { Standard } \\
\text { limits for } \\
\text { reuse }\end{array}$ \\
\hline $\mathrm{pH}$ & & $5.20-8.41$ & $6.5-8.5^{*}$ \\
\hline Temperature & ${ }^{\circ} \mathrm{C}$ & $24.8-38.9$ & NA \\
\hline $\begin{array}{c}\text { Electrical } \\
\text { conductivity (EC) }\end{array}$ & $\mathrm{mS} / \mathrm{cm}$ & $2.12-2.44$ & $<0.5^{\#}$ \\
\hline Turbidity & NTU & $24-550$ & $<1^{\#}$ \\
\hline $\begin{array}{l}\text { Dissolved oxygen } \\
\text { (DO) }\end{array}$ & $\mathrm{mg} / \mathrm{L}$ & $0-0.1$ & $3-5^{\#}$ \\
\hline $\begin{array}{c}\text { Chemical oxygen } \\
\text { demand (COD) }\end{array}$ & $\mathrm{mg} / \mathrm{L}$ & $250-1000$ & $50 *$ \\
\hline $\begin{array}{c}\text { Biochemical } \\
\text { oxygen demand } \\
\text { (BOD) }\end{array}$ & $\mathrm{mg} / \mathrm{L}$ & $80-550$ & $10 *$ \\
\hline $\begin{array}{c}\text { Total suspended } \\
\text { solids (TSS) }\end{array}$ & $\mathrm{mg} / \mathrm{L}$ & $200-1300$ & $20 *$ \\
\hline $\begin{array}{c}\text { Total dissolved } \\
\text { solids (TDS) }\end{array}$ & $\mathrm{mg} / \mathrm{L}$ & $250-5000$ & NA \\
\hline Total solids (TS) & $\mathrm{mg} / \mathrm{L}$ & $450-6300$ & NA \\
\hline Nitrate - Nitrogen & $\mathrm{mg} / \mathrm{L}$ & $44.1-121.0$ & $<5^{\#}$ \\
\hline $\begin{array}{c}\text { Ammonia - } \\
\text { Nitrogen }\end{array}$ & $\mathrm{mg} / \mathrm{L}$ & $36.2-89.1$ & NA \\
\hline Phosphate & $\mathrm{mg} / \mathrm{L}$ & $20.8-26.4$ & $<5^{\#}$ \\
\hline $\begin{array}{l}\text { Fecal Coliform } \\
\text { (FC) }\end{array}$ & $\begin{array}{c}\mathrm{MPN} / \\
100 \mathrm{~mL} \\
\end{array}$ & $\begin{array}{c}33 \times 10^{\wedge} 4- \\
54 \times 10^{\wedge} 6 \\
\end{array}$ & $<1000^{*}$ \\
\hline Oil and Grease & $\mathrm{mg} / \mathrm{L}$ & $1.2-3.0$ & $<1^{\#}$ \\
\hline
\end{tabular}

NA - Not Applicable; * - CPCB, 2015; \# - USEPA, 2003

The value of $\mathrm{pH}$ was found to be varying from acidic to alkaline (5.2-8.4) conditions. The reason may be the source of wastewater generated, if wastewater collected from Kitchen's then the wastewater has acidic content due citric acid if the 
wastewater collected from washing or laundry area then the pH will be alkaline due to surfactants (Eriksson et al., 2002; Igbinosa et al., 2009; Ramprasad and Philip, 2018). The $\mathrm{BOD} / \mathrm{COD}$ ratio was found to be $0.32-0.55$, means that the wastewater is containing some toxic pollutant that needs to be stabilized (Al-Isawi et al., 2017). The dissolved solids concentrations in the wastewater are also attributed by the kitchen and laundry waste. The nutrients concentrations in the wastewater are mainly due to urine and fecal waste added into the wastewater stream. The concentrations of the oil and grease levels in the wastewater is very less, the reason may be due to the life style of people.

Fig 5(a) Raw and treated water concentrations for rural area - $\mathrm{pH}$, turbidity and dissolved oxygen

Fig 5(b) Raw and treated water concentrations for rural area - COD, BOD and Oil and Grease

The treated water from the constructed wetland showed a very good removal of turbidity, chemical oxygen demand and biological oxygen demand with removal efficiencies of $98 \%$, $92 \%$ and $95 \%$ respectively. The $\mathrm{pH}$ of the treated water was in the range of $7.03 \pm 0.1$, the dissolved oxygen level also increased drastically reaching 3.2-3.5 mg/L (Figure 5(a)). The reason is due to the rhizomes or plants that provide atmospheric oxygen through the roots to the water. Similar kinds of results were shown by Ramprasad and Philip, 2018 that the rhizomes play a significant role in providing an aerobic nature to the treatment scheme. The COD and BOD also showed a significant reduction in the value, reaching $25 \pm 7 \mathrm{mg} / \mathrm{L}$ and $5.5 \pm 1.6 \mathrm{mg} / \mathrm{L}$ respectively (Figure $5(\mathrm{~b})$ ). The treated water is meeting the CPCB, 2015 standards limits for reuse (BOD - $10 \mathrm{mg} / \mathrm{L}$; COD - $50 \mathrm{mg} / \mathrm{L})$. The biological degradation and mutagenic adsorption process are the main mechanism involved in the reduction of BOD and COD respectively (Ulson et al., 2010; Valipour et al., 2015; AlIsawi et al., 2017; Ramprasad et al., 2017).

Fig 5(c) Raw and treated water concentrations for rural area - TSS, TDS and TS

Fig 5(d) Raw and treated water concentrations for rural area - Nitrate, Ammonia and Phosphate

The $\mathrm{NH}_{4}-\mathrm{N}$ and $\mathrm{NO}_{3}-\mathrm{N}$ in the effluent of the constructed wetlands were found to be $14.9 \pm 2.1 \mathrm{mg} / \mathrm{L}$ and $3.8 \pm 1.1 \mathrm{mg} / \mathrm{L}$ (Figure 5(d)). The wetland systems showed an improvement in the ammonia - nitrogen concentration reduction over time. The increase in nitrification process through the oxygenation of substrate could be the reason for decrease in ammonia - 
nitrogen concentration. At the early stage of experiments, the plants are not mature enough and later the growth was obtained to higher amount of oxygen transfer from atmosphere to root zone. Hence, the ammonia - nitrogen concentration in the effluent was more during initial stages of experiment and latter it decreases. Similar results were obtained by following literatures (Meng et al., 2014; Murphy et al., 2016; Al-Isawi et al., 2017). Moreover, the optimum conditions for the simultaneous nitrification and denitrification prevails in the wetlands with a good range of $\mathrm{pH}$ and temperature (Wang and $\mathrm{Li}, 2015$ ).

The suspended solids (SS) concentration in the treated water was found to be $15.2 \pm 5 \mathrm{mg} / \mathrm{L}$ and it was observed that the overtime the concentration was dropping. During the startup phase, the SS concentration was higher $18-26 \mathrm{mg} / \mathrm{L}$, and gradually reduced to $12-14 \mathrm{mg} / \mathrm{L}$ (Figure $5(\mathrm{c})$ ). The predominant mechanism responsible for the removal of SS was adsorption or filtration process. After the initial stages, the growth of plants was proliferated leading to spread of root and provided higher surface area for the filtration / sedimentation process to happen. Similar trend was obtained by Ramprasad and Philip, 2018; Al-Isawi et al., 2017; Paing et al., 2015; Korkusuz et al., 2005.

The average inflow and outflow phosphate concentration in the constructed wetlands are shown in Figure 5(d). The influent phosphate concentration varied significantly depending on the detergent usage (Yu et al., 2015). The phosphate are predominantly removed by the adsorption process and plant uptake. During the initial stages of experiments, it was noted that the phosphate concentration in the effluent was higher, and latter stages the concentration levels started to decrease. The reason is that during the startup period the growth level of plants is very minimal, hence only the adsorption process is considered as only predominant mechanism for removal. Similar results were seen in the study conducted by Ramprasad and Philip, 2018; Al-Isawi et al., 2017.

\subsection{Performance evaluation of urban DWWT}

It is seen from the Table 3 that, BOD was in the range of 330$580 \mathrm{mg} / \mathrm{L}$, and COD in the range of $625-1300 \mathrm{mg} / \mathrm{L}$. The BOD: COD ratio of the raw water was in the range of 0.29 to 0.54 , which is considered to be readily biodegradable and can be easily treated by biological means. The treated water was well within the standard limits for reuse for gardening established by CPCB 2015. The Figure 6(a) shows that, the dissolved oxygen level in the treated water has significantly increased from $<0.1 \mathrm{mg} / \mathrm{L}$ to $4-6.8 \mathrm{mg} / \mathrm{L}$. The drastic increase in the DO level is attributed to the constant air supply provided and proper maintenance. But, the turbidity level has not reached the desirable limit for reuse $(<1 \mathrm{NTU})$. The reason may be due to varying organic load factors leading to sloughing of biomass and clogging the filter beds. Similar type of reports were provided by Hayder et al., 2017.

The BOD of the treated water was $32-56 \mathrm{mg} / \mathrm{L}$, while COD was $64-137 \mathrm{mg} / \mathrm{L}$. The treated water does not meet the CPCB 2015 standard limits (BOD of $10 \mathrm{mg} / \mathrm{L}$ and COD of $50 \mathrm{mg} / \mathrm{L}$ ).
The oil and grease level in the raw wastewater was found to be in the range of 6.4 to $28 \mathrm{mg} / \mathrm{L}$ and in the treated water, 1.6 to $6.2 \mathrm{mg} / \mathrm{L}$. The oil and grease in the wastewater is mostly due to the cleaning of vessels and bathing. The oil and grease levels in the treated water are well within the CPCB 2015 standard limit for reuse $(<1 \mathrm{mg} / \mathrm{L})$ Figure $6(\mathrm{~b})$. The reason for the removal of organic pollutants in the MBBR systems is mainly due to the biodegradation process. The supply of oxygen and the biofilm development in the carriers are the important factor that govern the removal process (Biswas et al., 2014; Wan et al., 2016). It was also noted that the wastewater characteristics of the urban and rural regions are not significantly different.

Table 3. Urban wastewater characteristics

\begin{tabular}{|c|c|c|c|}
\hline Parameters & Unit & $\begin{array}{c}\text { Urban Wastewater } \\
\text { concentration }\end{array}$ & $\begin{array}{c}\text { CPCB } 2015 \\
\text { standard limits } \\
\text { for reuse }\end{array}$ \\
\hline $\mathrm{pH}$ & & $6.2-9.8$ & $6.5-8.5^{*}$ \\
\hline Temperature & ${ }^{\circ} \mathrm{C}$ & $20.6-24.7$ & NA \\
\hline $\begin{array}{c}\text { Electrical } \\
\text { conductivity (EC) }\end{array}$ & $\mathrm{mS} / \mathrm{cm}$ & NA & $<0.5^{\#}$ \\
\hline Turbidity & NTU & $313-982$ & $<1^{\#}$ \\
\hline $\begin{array}{l}\text { Dissolved oxygen } \\
\text { (DO) }\end{array}$ & $\mathrm{mg} / \mathrm{L}$ & $<0.1$ & $3-5^{\#}$ \\
\hline $\begin{array}{c}\text { Chemical oxygen } \\
\text { demand (COD) }\end{array}$ & $\mathrm{mg} / \mathrm{L}$ & $625-1300$ & $50 *$ \\
\hline $\begin{array}{l}\text { Biochemical } \\
\text { oxygen demand } \\
\text { (BOD) }\end{array}$ & $\mathrm{mg} / \mathrm{L}$ & $330-580$ & $10 *$ \\
\hline $\begin{array}{l}\text { Total suspended } \\
\text { solids (TSS) }\end{array}$ & $\mathrm{mg} / \mathrm{L}$ & $257-540$ & $20 *$ \\
\hline $\begin{array}{l}\text { Total dissolved } \\
\text { solids (TDS) }\end{array}$ & $\mathrm{mg} / \mathrm{L}$ & $1200-3554$ & NA \\
\hline Total solids (TS) & $\mathrm{mg} / \mathrm{L}$ & $1457-4094$ & NA \\
\hline Nitrate - Nitrogen & $\mathrm{mg} / \mathrm{L}$ & $49-70.1$ & $<5^{\#}$ \\
\hline $\begin{array}{l}\text { Ammonia - } \\
\text { Nitrogen }\end{array}$ & $\mathrm{mg} / \mathrm{L}$ & $28-60$ & NA \\
\hline Phosphate & $\mathrm{mg} / \mathrm{L}$ & $3.7-15.4$ & $<5^{\#}$ \\
\hline $\begin{array}{l}\text { Fecal Coliform } \\
\text { (FC) }\end{array}$ & $\begin{array}{c}\mathrm{MPN} / \\
100 \mathrm{~mL}\end{array}$ & $26 \times 10^{\wedge} 7-13 \times 10^{\wedge} 8$ & $<1000^{*}$ \\
\hline Oil and Grease & $\mathrm{mg} / \mathrm{L}$ & $6.4-28$ & $<1^{\#}$ \\
\hline
\end{tabular}

NA - Not Applicable; * - CPCB, 2015; * USEPA, 2003 
International Journal of Applied Engineering Research ISSN 0973-4562 Volume 14, Number 5 (2019) pp. 1135-1144

(C) Research India Publications. https://dx.doi.org/10.37622/IJAER/14.5.2019.1135-1144

Fig 6 (a) Raw and treated water concentrations for urban area $-\mathrm{pH}$, Turbidity and Dissolved Oxygen
Fig 6(c) Raw and treated water concentrations for urban area - TDS, TSS and TS
Fig 6(b) Raw and treated water concentrations for urban area - COD, BOD and Oil and grease

The suspended solids concentration in the raw wastewater varies from $257 \mathrm{mg} / \mathrm{L}$ to $540 \mathrm{mg} / \mathrm{L}$, and in the treated water is in the range of $15-38 \mathrm{mg} / \mathrm{L}$. It is seen that the treated water is well within the CPCB 2015 standard limits $(20 \mathrm{mg} / \mathrm{L})$ (Figure 6(c)). The removal of suspended solids occurs predominantly in the filtration process. The similar kind of results were reported by Chrispim and Nolasco, 2017, they found about $80-90 \%$ removal of SS concentration. They also conclude that removal highly depends on the working of aeration system. If the aeration system is not properly aerated, then the biomass carried forward to the subsequent system and clogging filtration system. Similar results were reported other literatures Ahmadi et al., 2013 and Persson et al., 2014.
Fig 6(d) Raw and treated water concentrations for urban area - Nitrate, Ammonia and Phosphate 


\subsection{Fecal coliform removal in the Urban and Rural wastewater treatment systems}

There is a stringent regulation put in-forth with respect to the fecal coliform or pathogen or microorganism level in the treated water. The presence of microorganism in the water leads to various health related problems in flora, fauna and to the humans as well. Therefore, the analysis of the microbial count is very vital for every treatment system. It was found that the standard microbial level in the treated water that can be utilized for secondary reuse purpose as per CPCB 2015 was found to be less than $1000 \mathrm{MPN} / 100 \mathrm{~mL}$. It was found that there was $4 \log$ reduction of the microorganism in the constructed wetland treatment process (Rural sector) and 3 log reduction in the MBBR treatment process (Urban sector) (Figure 7). In the urban sector, there was is a provision for the chlorination process (Figure 4), while in the constructed wetland there is no chlorination available. The chlorination is one of the common methods used in Indian conditions for the removal of pathogens from wastewater and it's economical too. But, interestingly it was observed that the level of coliform decrease was much higher in $\mathrm{CW}$ system than MBBR system. The reason may be due to symbiotic action of biodegradation, adsorption, plant uptake and the natural decay taking place. The $\mathrm{CW}$ also exposed to sunlight which provides natural UV rays for the decay of microbes, while the MBBR system is constructed beneath the car parking area. Similar results were obtained with $4-5 \log$ reduction of the coliform counts by the constructed wetland treatment for the municipal wastewater (Abou - Elela et al., 2013; Ramprasad et al., 2017).

Fig 7 Fecal coliform concentration in the urban and rural sectors raw and treated wastewater samples

\subsection{Overall performance}

The overall performance of the wastewater treatment systems in the rural and urban areas are provided in the Figure 8. It was found that, for the various parameters the constructed wetlands installed in the rural region showed a better removal than the urban MBBR system. The turbidity removal efficiency was found to be reaching $90 \pm 3.2 \%$ in the MBBR system, while it reached $96 \pm 4 \%$ in the CW system. Similar trend was seen for the other pollutants, COD showed a removal efficiency of $88 \pm 5.8 \%$ in the MBBR system and $94 \pm 3.2 \%$ in the CW system. The trend was slightly different in the case of ammonia removal, with both the systems shown almost similar level of removal. The reason for a better performance seen in the CW system is that the symbiotic action of adsorption, phytoremediation and biodegradation process taking place. The few photographs of the treatment system in the rural area and the raw and treated water (Figure 9).

Fig 8 Overall performance of the constructed wetland system (Rural area) and MBBR system (Urban area)

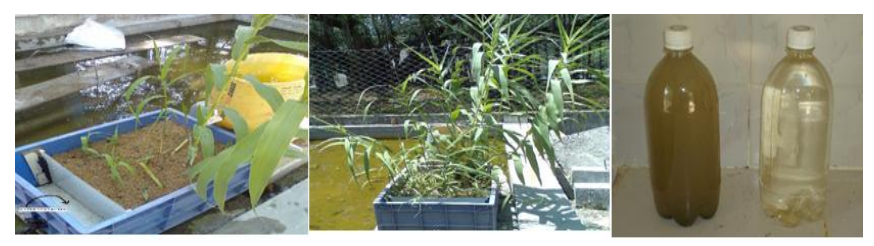

Fig 9 Photographs of the treatment systems and raw and treated water

\section{CONCLUSION}

The wastewater from the urban and rural sectors were characterized for the parameters such as $\mathrm{pH}$, turbidity, biochemical oxygen demand (BOD), chemical oxygen demand (COD), suspended solids (SS), dissolved solids, ammonia nitrogen, nitrate nitrogen, phosphate, fecal coliform and oil \& grease. It was found that the quality of the wastewater is not significantly different between the two sites. The ranges of $\mathrm{pH}$ was 5.2 - 9.8; turbidity was 24-982 NTU; BOD was $80-580 \mathrm{mg} / \mathrm{L}$; COD was $250-1300 \mathrm{mg} / \mathrm{L}$; SS was 200-1300 mg/L; ammonia nitrogen was $28-89.1 \mathrm{mg} / \mathrm{L}$; total phosphate was 3.7-26.4 $\mathrm{mg} / \mathrm{L}$ and fecal coliform level was $33 \times 10^{\wedge} 4-13 \times 10^{\wedge} 8 \mathrm{MPN} / 100 \mathrm{~mL}$. The removal of the pollutants were found to be better in the constructed wetland treatment system than MBBR system. The study provides an evidence that the decentralized approach is the future wastewater treatment solutions, due to enormous load on centralized systems. 


\section{REFERENCES}

[1] Abou-Elela, S. I., Golinielli, G., Abou-Taleb, E. M., \& Hellal, M. S. (2013). Municipal wastewater treatment in horizontal and vertical flows constructed wetlands. Ecological Engineering, 61, 460-468.

[2] Ahmadi, M., Alavi, N. A. D. A. L. I., Jaafarzadeh, N. E. M. A. T. O. L. L. A. H., Ghaedrahmat, Z., \& Hashemi, F. (2013). Performance evaluation of moving bed bio film reactor in saline wastewater treatment.

[3] Al-Isawi, R., Ray, S., \& Scholz, M. (2017). Comparative study of domestic wastewater treatment by mature vertical-flow constructed wetlands and artificial ponds. Ecological engineering, 100, 8-18.

[4] Apha, A. W. W. A. (2012). WEF.(2012). Standard methods for the examination of water and wastewater, 22.

[5] Bassin, J. P., Kleerebezem, R., Dezotti, M., \& Van Loosdrecht, M. C. M. (2012). Simultaneous nitrogen and phosphate removal in aerobic granular sludge reactors operated at different temperatures. Water Research, 46(12), 3805-3816.

[6] Bdour, A. N., Hamdi, M. R., \& Tarawneh, Z. (2009). Perspectives on sustainable wastewater treatment technologies and reuse options in the urban areas of the Mediterranean region. Desalination, 237(1-3), 162-174.

[7] Biswas, K., Taylor, M. W., \& Turner, S. J. (2014). Successional development of biofilms in moving bed biofilm reactor $(\mathrm{MBBR})$ systems treating municipal wastewater. Applied microbiology and biotechnology, 98(3), 1429-1440.

[8] Bukhari, A. A. (2008). Investigation of the electrocoagulation treatment process for the removal of total suspended solids and turbidity from municipal wastewater. Bioresource technology, 99(5), 914-921.

[9] Chen, Y., Vymazal, J., Březinová, T., Koželuh, M., Kule, L., Huang, J., \& Chen, Z. (2016). Occurrence, removal and environmental risk assessment of pharmaceuticals and personal care products in rural wastewater treatment wetlands. Science of the Total Environment, 566, 1660-1669.

[10] Chrispim, M. C., \& Nolasco, M. A. (2017). Greywater treatment using a moving bed biofilm reactor at a university campus in Brazil. Journal of Cleaner Production, 142, 290-296.

[11] Cossio, C., McConville, J., Rauch, S., Wilén, B. M., Dalahmeh, S., Mercado, A., \& Romero, A. M. (2018). Wastewater management in small townsunderstanding the failure of small treatment plants in Bolivia. Environmental technology,39(11), 13931403.

[12] CPCB (2017) Assessment of pollution of drains carrying sewage/industrial effluent joining River
Ganga and its tributaries. A joint report by Uttar Pradesh Jal Nigam (UPJN), Uttar Pradesh Pollution Control Board (UPPCB), Lucknow and Central Pollution Control Board (CPCB).

[13] Eriksson, E., Auffarth, K., Henze, M., \& Ledin, A. (2002). Characteristics of grey wastewater. Urban water, 4(1), 85-104.

[14] Halalsheh, M., Dalahmeh, S., Sayed, M., Suleiman, W., Shareef, M., Mansour, M., \& Safi, M. (2008). Grey water characteristics and treatment options for rural areas in Jordan. Bioresource technology, 99(14), 6635-6641.

[15] Hayder, G., Ahmed, A. N., \& Fu'ad, N. F. S. M. (2017). A review on media clogging in attached growth system. Int. J. Appl. Eng. Res, 12, 8034-8039.

[16] Igbinosa, E. O., Obi, L. C., \& Okoh, A. I. (2009). Occurrence of potentially pathogenic vibrios in final effluents of a wastewater treatment facility in a rural community of the Eastern Cape Province of South Africa. Research in microbiology, 160(8), 531-537.

[17] Kaur, R., Wani, S. P., Singh, A. K., \& Lal, K. (2012, May). Wastewater production, treatment and use in India. In National Report presented at the 2 nd regional workshop on Safe Use of Wastewater in Agriculture.

[18] Korkusuz, E. A., Beklioğlu, M., \& Demirer, G. N. (2005). Comparison of the treatment performances of blast furnace slag-based and gravel-based vertical flow wetlands operated identically for domestic wastewater treatment in Turkey. Ecological Engineering, 24(3), 185-198.

[19] Leitão, R. C., Van Haandel, A. C., Zeeman, G., \& Lettinga, G. (2006). The effects of operational and environmental variations on anaerobic wastewater treatment systems: a review. Bioresource technology, 97(9), 1105-1118.

[20] Meng, P., Pei, H., Hu, W., Shao, Y., \& Li, Z. (2014). How to increase microbial degradation in constructed wetlands: influencing factors and improvement measures. Bioresource technology, 157, 316-326.

[21] Murphy, F., Ewins, C., Carbonnier, F., \& Quinn, B. (2016). Wastewater treatment works (WwTW) as a source of microplastics in the aquatic environment. Environmental science \& technology, 50(11), 5800-5808.

[22] Paing, J., Guilbert, A., Gagnon, V., \& Chazarenc, F. (2015). Effect of climate, wastewater composition, loading rates, system age and design on performances of French vertical flow constructed wetlands: a survey based on 169 full scale systems. Ecological Engineering, 80, 46-52.

[23] Parkinson, J., \& Tayler, K. (2003). Decentralized wastewater management in peri-urban areas in low- 
income countries. Environment and Urbanization, 15(1), 75-90.

[24] Persson, F., Sultana, R., Suarez, M., Hermansson, M., Plaza, E., \& Wilén, B. M. (2014). Structure and composition of biofilm communities in a moving bed biofilm reactor for nitritation-anammox at low temperatures. Bioresource technology, 154, 267-273.

[25] Ramprasad, C., \& Kutty, M. (2016). Recycling of domestic wastewater by subsurface flow constructed wetland for construction purposes. International Journal of Environment and Sustainable Development, 15(3), 286-292.

[26] Ramprasad, C., \& Philip, L. (2018). Greywater treatment using horizontal, vertical and hybrid flow constructed wetlands. Current Science (00113891), 114(1).

[27] Ramprasad, C., Smith, C. S., Memon, F. A., \& Philip, L. (2017). Removal of chemical and microbial contaminants from greywater using a novel constructed wetland: GROW. Ecological Engineering, 106, 55-65.

[28] Tchobanoglous, G., Burton, F. L., \& Stensel, H. D. (2003). Wastewater engineering treatment and reuse (No. 628.3 T252s). Boston, US: McGraw-Hill Higher Education.

[29] Ulson, S. M. D. A. G., Bonilla, K. A. S., \& de Souza, A. A. U. (2010). Removal of COD and color from hydrolyzed textile azo dye by combined ozonation and biological treatment. Journal of Hazardous Materials, 179(1-3), 35-42.

[30] Valipour, A., Raman, V. K., \& Ahn, Y. H. (2015). Effectiveness of domestic wastewater treatment using a bio-hedge water hyacinth wetland system. Water, 7(1), 329-347.

[31] Wan, J., Gu, J., Zhao, Q., \& Liu, Y. (2016). COD capture: a feasible option towards energy selfsufficient domestic wastewater treatment. Scientific reports, 6, 25054.

[32] Wang, L., \& Li, T. (2015). Effects of seasonal temperature variation on nitrification, anammox process, and bacteria involved in a pilot-scale constructed wetland. Environmental Science and Pollution Research, 22(5), 3774-3783.

[33] Wu, H., Fan, J., Zhang, J., Ngo, H. H., Guo, W., Hu, Z., \& Liang, S. (2015). Decentralized domestic wastewater treatment using intermittently aerated vertical flow constructed wetlands: impact of influent strengths. Bioresource technology, 176, 163-168.

[34] Yu, J., Liang, W., Wang, L., Li, F., Zou, Y., \& Wang, H. (2015). Phosphate removal from domestic wastewater using thermally modified steel slag. Journal of Environmental Sciences, 31, 81-88. 